\title{
UPAYA MENINGKATKAN HASIL BELAJAR IPA MENGGUNAKAN PEMBELAJARAN KOOPERATIF TIPE JIGSAW SISWA KELAS IV SDN 163088 KOTA TEBING TINGGI
}

\author{
Isnayani Siregar \\ Surel : isnayani_regar@gmail.com
}

\begin{abstract}
The purpose of the study was to improve student learning outcomes in the material structure and function of plant parts of class IV 163088 Public Elementary School Jalan Nangka Tebing city using Jigsaw cooperative learning type. This study uses the Kemis Mc Targart method, in each cycle consisting of activities of planning, implementation, observation and reflection. This research was conducted in 2 cycles. The subjects of this study were fourth grade students of SDN 163088 in Tebing Tinggi city, totaling 22 students. This study uses qualitative descriptive analysis techniques. Data analysis was collected through tests. Science using Jigsaw type cooperative learning can improve learning outcomes of class IV students at SD Negeri 163088 Tebingtinggi. This can be seen from the results of the tests obtained during the pre-cycle where the average score of the acquisition of students was 62.5 with classical completeness of $40.9 \%$. After carrying out the first cycle and carried out the test at the end of the first cycle, there was an increase in students' understanding with the student average score of 74.3 and the classical completeness value of $72.7 \%$. the test results obtained in the second cycle the average value of students is 80.22 with class completeness of $90.90 \%$, hence this research is said to be successful.
\end{abstract}

Keywords: Learning Outcomes, Plant Structure, Jigsaw

\begin{abstract}
ABSTRAK
Tujuan penelitian untuk meningkatkan hasil belajar siswa pada materi struktur dan fungsi bagian tumbuhan siswa kelas IV SD Negeri 163088 Jalan Nangka kota Tebing tinggi dengan menggunakan pembelajaran kooperatif tipe Jigsaw. Penelitian ini menggunakan metode Kemis Mc Targart, dalam setiap siklusnya terdiri dari kegiatan perencanaan, pelaksanaan, observasi dan refleksi. Penelitian ini dilaksanakan sebanyak 2 siklus. Subjek penelitian ini adalah siswa kelas IV SDN 163088 kota Tebing tinggi yang berjumlah 22 siswa. Penelitian ini menggunakan teknik analisis dekriptif kualitatif. Analisis data pada dikumpulkan melalui tes. IPA dengan menggunakan pembelajaran kooperatif tipe Jigsaw dapat meningkatkan hasil belajar siswa kelas IV SD Negeri 163088 kota Tebingtinggi. Hal Ini dapat dilihat dari hasil tes yang diperoleh saat pra siklus dimana nilai rata -rata perolehan siswa 62,5 dengan ketuntasan klasikal 40,9\%. Setelah dilaksanakan siklus I dan dilaksanakan tes diakhir siklus I terjadi peningkatan pemahaman siswa dengan nilai rata-rata perolehan siswa sebesar 74,3 dan nilai ketuntasan klasikal sebesar $72,7 \%$. hasil tes yang diperoleh pada siklus II nilai rata-rata siswa 80,22 dengan ketuntasan kelas sebesar 90,90\% , maka dengan ini penelitian ini dikatakan berhasil.
\end{abstract}

Kata Kunci : Hasil Belajar, Struktur Tumbuhan, Jigsaw 

Isnayani Siregar: Upaya Meningkatkan Hasil Belajar...

\section{PENDAHULUAN}

Aktivitas pendidikan bukan hanya sebatas proses transpormasi pembelajaran pengetahuan, keterampilan dan kebiasaan sekelompok orang yang diturunkan dari satu generasi ke generasi berikutnya melalui pengajaran, pelatihan atau penelitian. Lebih luas lagi pendidikan adalah sebuah aktivitas yang sengaja dirancang untuk menciptakan generasi penerus yang memiliki wawasan yang luas, budi pekerti yang mulia, terampil, bertanggung jawab dan bertakwa kepada Tuhan Yang Maha Esa. Pendidikan dapat terjadi di bawah bimbingan orang lain, tetapi juga memungkinkan secara otodidak. Pendidikan mempunyai misi untuk mengembangkan potensi yang dimiliki siswa agar menjadi generasi yang cerdas dan memiliki moral yang baik serta berbudi luhur sesuai dengan jati diri bangsa. Melalui pendidikan siswa dapat mengenal berbagai hal untuk mengembangkan diri secara optimal. Potensi siswa dapat berkembang karena didukung oleh tenaga yang berkompeten, yaitu guru. Guru dipandang sebagai orang yang sangat berpengaruh dalam menghantarkan siswa untuk mencapai tujuan belajarnya. Guru yang merangkap sebagai orang tua bagi siswa menjadi sosok yang sangat diharapkan keberadaannya untuk membantu siswa agar memiliki kepribadian yang baik sehingga bisa menjadi generasi yang unggul.
Ilmu Pengetahuan Alam merupakan salah satu pelajaran dasar yang harus dikuasai siswa sejak sekolah dasar. Penguasaan terhadap bidang IPA sangat diperlukan siswa sebagai bekal hidupnya dalam menghadapi perkembangan ilmu pengetahuan dan teknologi yang semakin pesat. Siswa diharapkan mempunyai pengetahuan IPA yang cukup mampu menerapkannya dalam menghadapi berbagai masalah yang timbul dalam kehidupan sehari-hari. Beberapa permasalahan yang terkait dengan hasil belajar muatan IPA yaitu (1) masih banyak siswa yang rendah hasil belajarnya dalam muatan Ilmu Pengetahuan Alam. Hal ini dapat dilihat dari hasil nilai hasil ujian tengah semester siswa, rata-rata nilai yang diperoleh siswa tidak mencapai kriteria ketuntasan minimum yang telah ditentukan, (2) dikarenakan mata pelajaran muatan IPA dikenal terlalu banyak teori dan terkesan membosankan, sehingga siswa seringkali mencapai kesibukan lain seperti bermain dengan temannya dan membuat keributan di kelas, (3) guru cenderung menoton dalam mengajar dan tidak menggunakan metode belajar yang baru untuk membangkitkan semangat siswa dalam belajar agar hasil belajar yang dicapai lebih maksimal dan meningkat, dan (4) sarana dan prasarana disekolah masih kurang untuk menunjang proses pembelajaran muatan IPA. IPA didefiniksan sebagai suatu kumpulan pengetahuan yang tersusun secara alam. Perkembangan 


\section{SCHOOL EDUCATION JOURNAL VOLUME 9 NO. 2 JUNI 2019}

IPA tidak hanya ditandai dengan adanya fakta, tetapi juga oleh adanya metode ilmiah dan sikap ilmiah. Metode ilmiah dan pengamatan ilmiah menekankan pada hakikat IPA. Secara rinci hakikat IPA menurut Bridgman (dalam Lestari, 2002:7) adalah sebagai berikut: Kualitas; pada dasarnya konsepkonsep IPA selalu dapat dinyatakan dalam bentuk angka-angka.

Observasi dan Eksperimen; merupakan salah satu cara untuk dapat memahami konsep-konsep IPA secara tepat dan dapat diuji kebenarannya. Ramalan (prediksi); merupakan salah satu asumsi penting dalam IPA bahwa misteri alam raya ini dapat dipahami dan memiliki keteraturan. Dengan asumsi tersebut lewat pengukuran yang teliti maka berbagai peristiwa alam yang akan terjadi dapat diprediksikan secara tepat. Progresif dan komunikatif; artinya IPA itu selalu berkembang ke arah yang lebih sempurn dan penemuan-penemuan yang ada merupakan kelanjutan dari penemuan sebelumnya. Proses; tahapan-tahapan yang dilalui dan itu dilakukan dengan menggunakan metode ilmiah dalam rangkan menemukan suatu kebenaran. Universalitas; kebenaran yang ditemukan senantiasa berlaku secara umum. Pembelajaran kooperatif adalah salah satu bentuk pembelajaran yang berdasarkan faham konstruktivis. Pembelajaran kooperatif merupakan strategi belajar dengan sejumlah siswa sebagai anggota kelompok kecil yang tingkat kemampuannya

berbeda.
Berdasarkan prinsip-prinsip yang dikemukakan oleh Kagan dan Slavin hakikat pembelajaran kooperatif adalah adanya keterlibatan seluruh siswa dalam suatu kelompok yang terstruktur. Struktur kelompok tersebut meliputi struktur tugas, struktur tujuan,dan struktur penghargaan (reward).

Tipe Jigsaw adalah salah satu tipe pembelajaran kooperatif di mana pembelajaran melalui penggunaan kelompok kecil siswa yang bekerja sama dalam memaksimalkan kondisi belajar untuk mencapai tujuan pembelajaran dan mendapatkan pengalaman belajar yang maksimal, baik pengalaman individu maupun pengalaman pada kelompok. Pada pembelajaran kooperatif tipe Jigsaw ini setiap siswa menjadi anggota dari 2 kelompok, yaitu anggota kelompok asal dan anggota kelompok ahli. Anggota kelompok asal terdiri dari 3-5 siswa yang setiap anggotanya diberi nomor kepala 1-5. Nomor kepala yang sama pada kelompok asal berkumpul pada suatu kelompok yang disebut kelompok ahli.

Dalam pembelajaran kooperatif tipe Jigsaw terdapat 3 karakteristik yaitu: a. kelompok kecil, b. belajar bersama, dan c. pengalaman belajar. Esensi kooperatif learning adalah tanggung jawab individu sekaligus tanggung jawab kelompok, sehingga dalam diri siswa terbentuk sikap ketergantungan positif yang menjadikan kerja kelompok optimal. Keadaan ini mendukung siswa dalam kelompoknya belajar bekerja sama 
dan tanggung jawab dengan sungguh-sungguh sampai suksesnya tugas-tugas dalam kelompok. Hal ini sesuai dengan pendapat yang dikemukakan oleh Johnson (1991: 27) yang menyatakan bahwa "Pembelajaran Kooperatif tipe Jigsaw ialah kegiatan belajar secara kelompok kecil, siswa belajar dan bekerja sama sampai kepada pengalaman belajar yang maksimal, baik pengalaman individu maupun pengalaman kelompok".

\section{METODE PENELITIAN}

Penelitian ini merupakan penelitian tindakan kelas (action research), karena penelitian dilakukan untuk memecahkan masalah pembelajaran di kelas. Penelitian ini juga termasuk penelitian deskriptif, sebab menggambarkan bagaimana suatu teknik pembelajaran diterapkan dan bagaimana hasil yang diinginkan dapat dicapai. Dalam penelitian tindakan ini menggunakan bentuk guru sebagai peneliti, penanggung jawab penuh penelitian ini adalah guru. Tujuan utama dari penelitian tindakan ini adalah untuk meningkatkan hasil pembelajaran di kelas dimana guru secara penuh terlibat dalam penelitian mulai dari perencanaan, tindakan, pengamatan, dan refleksi.

Subjek pada penelitian ini adalah siswa-siswa kelas IV SD Negeri 163088 yang beralamat di Jalan Nangka kota Tebingtinggi tahun pelajaran 2017/2018 yang berjumlah 22 orang, dengan rincian
10 laki-laki dan 12 perempuan. Ratarata usia siswa yang menjadi subjek pada penelitian ini adalah antara 1011 tahun.

Tempat penelitian adalah tempat yang digunakan dalam melakukan penelitian untuk memperoleh data yang diinginkan. Penelitian ini bertempat di Kelas IV SD Negeri 163088 Jalan Nangka kota Tebingtinggi.

Waktu penelitian adalah waktu berlangsungnya kegiatan penelitian atau saat penelitian ini dilangsungkan. Penelitian ini dilaksanakan mulai pada bulan Januari sampai dengan Juni semester genap tahun pelajaran 2017/2018. Siklus I dilaksanakan pada hari selasa tanggal 7 Agustus 2017, sedangkan siklus II dilaksanakan pada hari Selasa tanggal 4 September 2017.

Sesuai dengan jenis penelitian yang dipilih, yaitu penelitian tindakan, maka penelitian ini menggunakan model penelitian tindakan dari Kemmis dan Taggart (dalam Sugiarti, 1997: 6), yaitu berbentuk spiral dari sklus yang satu ke siklus yang berikutnya. Setiap siklus meliputi planning (rencana), action (tindakan), observation (pengamatan), dan reflection (refleksi). Pada penelitian ini menggunakan teknik analisis deskriptif kualitatif, yaitu suatu metode penelitian yang bersifat menggambarkan kenyataan atau fakta sesuai dengan data yang diperoleh dengan tujuan untuk mengetahui prestasi belajar yang 
dicapai peserta didik juga untuk memperoleh respon peserta didik terhadap kegiatan pembelajaran serta aktivitas peserta didik selama proses pembelajaran.

Untuk mengalisis tingkat keberhasilan atau persentase keberhasilan peserta didik setelah proses belajar mengajar setiap putarannya dilakukan dengan cara memberikan evaluasi berupa soal tes tertulis pada setiap akhir putaran.

Peneliti yang melakukan penjumlahan nilai yang diperoleh peserta didik, yang selanjutnya dibagi dengan jumlah peserta didik yang ada di kelas tersebut sehingga diperoleh rata-rata tes formatif dapat dirumuskan:

$$
\begin{array}{ll} 
& \overline{\boldsymbol{X}}=\frac{\sum X}{\sum N} \\
\bar{X} & =\text { Nilai rata-rata } \\
\Sigma \mathrm{X} & =\text { Jumlah semua nilai peserta } \\
& \text { didik } \\
\Sigma \mathrm{N} \quad & =\text { Jumlah peserta didik }
\end{array}
$$

Berdasarkan petunjuk
pelaksanaan belajar mengajar kurikulum 1994 (Depdikbud, 1994), yaitu seorang peserta didik telah tuntas belajar bila telah mencapai skor $65 \%$ atau nilai 65 , dan kelas disebut tuntas belajar bila di kelas tersebut terdapat $80 \%$ yang telah mencapai daya serap lebih dari atau sama dengan 65\%. Untuk menghitung persentase ketuntasan belajar digunakan rumus sebagai berikut:

$$
P=\frac{\sum \text { Siswa.yang.tuntas.belajar }}{\sum \text { Siswa }} \times 100 \%
$$

\section{HASIL PENELITIAN DAN PEMBAHASAN}

Dari hasil observasi dan tes diakhir pelajaran yang dilakukan terhadap dua puluh dua (22) siswa kelas IV SD Negeri 163088 Jalan Nangka Kota Tebingtinggi di awal kegiatan sebelum dilakukan siklus I. peneliti melakukan kegiatan penelitian pada siklus satu dengan tujuan untuk meningkatkan kemampuan dan pemahaman siswa terhadap materi struktur dan fungsi bagian tumbuhan dengan menggunakan metode kooperatif tipe Jigsaw siswa kelas IV SD Negeri 163088 Jalan nangka kota Tebingtinggi tahun pembelajaran 2017/2018.

\section{Siklus I}

Sebelum siklus I dilaksanakan peneliti menyusun perencanaan terhadap kegiatan penelitian yang akan dilakukan. Persiapan perlu dilakukan agar kegiatan penelitian dapat berjalan dengan baik agar terjadi peningkatan kemampuan siswa pada pelajaran ilmu pengetahuan alam khusunya pada materi struktur dan fungsi bagian tumbuhan. Adapun kegiatan yang dilakukan oleh peneliti adalah: merancang rencana pelaksanaan pembelajaran dengan menggunakan metode pembelajaran kooperatif tipe Jigsaw yang akan dipergunakan dalam penelitian, menyusun lembar observasi pembelajaran yang akan dipergunakan dalam pelaksanaan pembelajaran, merancang bahan bacaan bagi tim ahli yang akan 
Isnayani Siregar: Upaya Meningkatkan Hasil Belajar...

dipergunakan dalam kegiatan pembelajaran menggunakan metode pembelajaran kooperatif tipe Jigsaw. Berdasarkan hasil tes yang dilakukan di akhir siklus I terlihat pemahaman siswa terhadap materi struktur dan fungsi bagian tumbuhan menjadi lebih meningkat jika dibandingkan dengan keadaan pada pra siklus. Hal ini terjadi dikarenakan siswa merasa lebih memahami materi disebabkan dalam memahami materi struktur dan bagian gungsi bagian tumbuhan, mereka mendapatkannya dengan cara yang berbeda dari kegiatan pembelajaran sebelumnya. Jika pada pembelajaran sebelumnya, mereka hanya mendengarkan materi dari penjelasan guru, namun pada kegiatan pembelajaran ini mereka memperolehnya dari pemahaman mereka sendiri sebagai tim ahli dan melalui penjelasan teman dalam kegiatan tutor sebaya. Tingkat ketuntasan belajar siswa pada siklus I dapat dilihat pada grafik berikut :

\section{Jumlah Siswa}

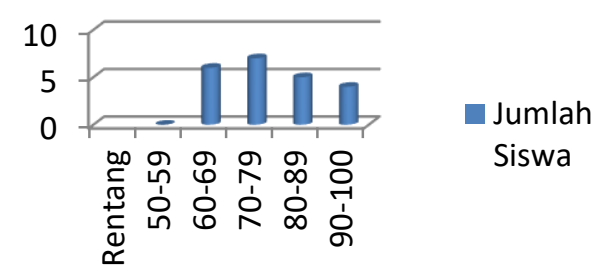

\section{Grafik 1. Daftar Nilai Siswa Pada Siklus I}

Dari gambar diatas dapat dilihat bahwa kemampuan siswa dalam memahami materi struktur dan fungsi bagian tumbuhan berdasarkan hasil tes yang dilakukan setelah siklus I selesai dilaksanakan sudah makin meningkat jika dibandingkan dengan hasil perolehan nilai pada kegiatan pra siklus. Jika pada pra siklus jumlah siswa yang berada pada interval nilai 50-59 pada pra siklus berjumlah 5 siswa $(22,7 \%)$ maka pada siklus I sudah tidak ada lagi siswa yang memperoleh nilai tersebut, untuk interval nilai 60-69 jika pada kegiatan pra siklus ada delapan siswa (36,3\%), maka setelah siklus I dilaksanakan jumlah siswa yang memperoleh nilai pada rentang tersebut berkurang menjadi enam siswa (27\%). Untuk interval nilai 70 79 jika pada pra siklus hanya 1 siswa $(4,5 \%)$ maka pada siklus I meningkat menjadi 7 siswa (32\%), interval 8089 jika pada pra siklus ada 5 siswa $(22,7 \%)$ maka pada siklus I jumlah siswa yang memperoleh interval tersebut tetap sama yaitu sebanyak 5 siswa $(22,7 \%)$ dan interval nilai 90 100 jika pada pra siklus hanya ada 3 siswa $(13,6 \%)$ maka pada siklus I meningkat menjadi 4 siswa (18\%)

Dari data di atas terlihat kemampuan siswa meningkat setelah guru mengajar mata pelajaran ilmu pengetahuan alam pada materi 
struktur dan fungsi bagian tumbuhan dengan menggunakan metode kooperatif tipe jigsaw. Hal ini juga bisa kita lihat pada persentase pencapaian secara klasikal terhadap KKM yang telah ditentukan. Jika pada kegiatan pra siklus pencapaian presentase secara klasikal hanya mencapai 40,9\% maka pada siklus I telah mencapai $72,7 \%$ terjadi peningkatan sekitar $31.8 \%$ jika dibandingkan dengan pra siklus.

Berdasarkan hasil perolehan nilai yang diperoleh dari tes setelah siklus I dilaksanakan, maka dapat diambil kesimpulan bahwa terjadi peningkatan kemampuan siswa pada materi struktur dan fungsi bagian tumbuhan. Peningkatan terjadi dikarenakan peneliti menggunakan metode kooperatif tipe Jigsaw, namun hasil ketuntasan yang diperoleh belum sesuai dengan indicator yang ditetapkan yaitu ratarata persentase pencapaian klasikal siswa $80 \%$. Bedasarkan hasil siklus I maka penelitian ini dilanjutkan pada siklus II.

Adapun hasil refleksi yang dilakukan pada siklus I adalah sebagai berikut : (a) masih ada siswa kurang serius membaca bahan bacaan yang diberrikan oleh guru sebagai tim ahli (b) waktu yang dibutuhkan dalam pembentukan kelompok ahli sangat lama dikarenakan proses pembentukan kelompok di dalam kelas sehingga siswa susah untuk berpindah tempat Berdasarkan hasil temuan tersebut maka pada siklus II yang menjadi masukan bagi peneliti untuk menjadi perbaikan agar hasil yang diperoleh menjadi lebih baik jika dibandingkan dengan siklus I adalah : (a) guru akan melakukan mobilisasi ke seluruh kelompok untuk memberikan motivasi dan semangat bagi siswa dalam membacakan bacaan sebagai tim ahli, (b) pembentukan kelompok ahli akan dilaksanakan di luar kelas dan memanfaatkan lingkungan sebagai sumber belajar. Melihat hasil yang diperoleh pada siklus I belum sesuai dengan indicator yang telah ditentukan pada penelitian ini, maka penelitian ini dilanjutkan pada siklus berikutnya yaitu siklus II.

\section{Siklus II}

Sebelum siklus II dilaksanakan sama halnya dengan yang dilakukan pada siklus I, peneliti menyusun perencanaan terhadap kegiatan penelitian yang akan dilakukan. Adapun kegiatan yang dilakukan oleh peneliti adalah: merancang rencana pelaksanaan pembelajaran dengan menggunakan metode pembelajaran kooperatif tipe Jigsaw yang akan dipergunakan dalam penelitian, menyusun lembar observasi pembelajaran yang akan dipergunakan dalam pelaksanaan pembelajaran, merancang bahan bacaan bagi tim ahli yang akan dipergunakan dalam kegiatan pembelajaran menggunakan metode pembelajaran kooperatif tipe Jigsaw, Dan menentukan indicator keberhasilan penelitian yang akan dipergunakan sebagai standar pengukuran keberhasilan penelitian. Tindakan yang diberikan guru pada 
siklus II ini, sebagian besar kegiatannya sama dengan yang dilakukan pada siklus I. Perbedaan yang mendasar adalah berdasarkan hasil observasi dan refleksi yang dilakukan di akhir siklus I, maka kegiatan saat siswa bekerja sebagai tim ahli, kegiatannya dengan memanfaatkan lingkungan sekolah. Maksudnya saat siswa dikelompokkan dalam tim ahli, guru menugaskan anak untuk berdiskusi di luar kelas. Setelah kegiatan belajar mengajar selesai dilakukan, dan berdasarkan hasil tes yang dilakukan di akhir siklus II terlihat pemahaman siswa terhadap materi yang terdapat dalam pelajaran ilmu pengetahuan alam menjadi lebih meningkat jika dibandingkan dengan keadaan pada siklus I. Tingkat ketuntasan belajar siswa pada siklus II dapat dilihat pada diagram berikut:

\section{Jumlah Siswa}

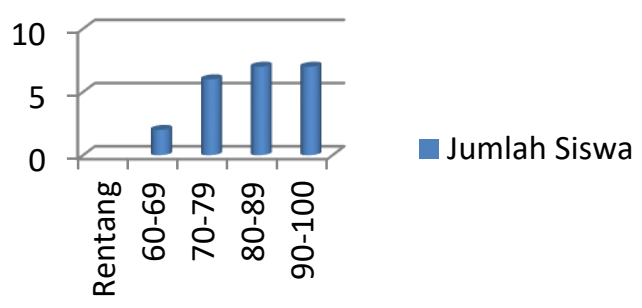

\section{Grafik 2. Daftar Nilai Siswa Pada Siklus II}

Dari gambar dan table diatas dapat dilihat bahwa kemampuan siswa dalam memahami materi daur hidup hewan berdasarkan hasil tes yang dilakukan setelah siklus II sudah makin meningkat jika dibandingkan dengan hasil perolehan nilai pada kegiatan pada siklus I. Jika pada siklus I jumlah siswa yang berada pada interval nilai 60-69 berjumlah 6 siswa (27\%) maka pada siklus II hanya tinggal 2 siswa (9\%) dan kedua siswa tersebut adalah siswa yang juga belum tuntas dari 22 jumlah siswa kelas IV SD Negeri 163088 Jalan Nangka Kota Tebingtinggi. Untuk interval nilai 70-79 jika pada siklus I sebanyak 7 siswa $(32 \%)$ maka pada siklus II hanya 6 siswa (27\%), interval 80-89 jika pada siklus I hanya 5 siswa (23\%) maka pada siklus II meningkat menjadi 7 siswa (32\%) dan interval tertinggi yaitu 90 - 100 jika pada siklus I hanya ada 4 siswa ( $18 \%$ ) yang berhasil memperolehnya, maka pada siklus II untuk interval 90-100 meningkat menjadi 7 siswa $(32 \%)$ yang berhasil memperolehnya. Dari data di atas terlihat kemampuan siswa meningkat setelah guru mengajar pendidikan ilmu pengetahuan alam dengan menggunakan metode pembelajaran kooperatif tipe Jigsaw. Hal ini juga bisa kita lihat pada persentase pencapaian secara klasikal terhadap KKM yang telah ditentukan. Jika 
pada kegiatan siklus I pencapaian presentase secara klasikal hanya mencapai $72,7 \%$ maka pada siklus II telah mencapai $90,90 \%$ terjadi peningkatan sekitar $18.2 \%$ setelah dilaksanakan siklus II.

Hasil observasi yang dilakukan pada siklus II, menunjukkan semangat dan antusias siswa dalam mengikuti proses pembelajaran dengan menggunakan metode pembelajaran kooperatif sangat tinggi. Guru juga dalam melakukan proses pembelajaran telah mengikuti seluruh langkah-langkah yang disusun dalam rencana pelaksanaan pembelajaran dengan menggunakan metode pembelajaran kooperatif tipe Jigsaw. Secara keseluruhan proses pembelajaran berlangsung baik dan siswa semangat dalam kegiatan belajar.

Setelah siklus II selesai dilaksanakan dan berdasarkan hasil observasi yang dilakukan oleh observer dengan menggunakan lembar observasi yang telah disediakan terlihat proses pembelajaran telah berjalan dengan baik, siswa semangat mengikuti pelajaran. Segala masukan yang disarankan pada siklus I telah dilaksanakan sehingga proses pembelajaran menjadi lebih baik dan memperoleh hasil sesuai dengan apa yang diharapkan. Pada awal pertemuan sebelum siklus I dilaksanakan, peneliti melakukan pretes yang bertujuan untuk mengetahui kemampuan awal siswa sebelum penelitian dimulai. Nilai rata-rata pretes siswa pada mata pelajaran ilmu pengetahuan alam materi struktur dan fungsi bagian tumbuhan adalah 62,5 dengan persentase $40,9 \%$. Nilai yang diperoleh siswa pada hasil pretes pra siklus ini sangat rendah, hasil ini diperoleh dari tes yang dilakukan sebelum siswa mendapatkan materi dengan menggunakan metode kooperatif tipe Jigsaw.

\section{Pembahasan}

Selanjutnya pelaksanaan kegiatan belajar mengajar (KBM) dilaksanakan sesuai dengan metode kooperatif tipe Jigsaw yang telah dirancang oleh peneliti. Berdasarkan deskripsi yang telah dirancang dalam penelitian maka kegiatan belajar mengajar (KBM) pada siklus I dilakukan dengan menekankan pada materi-materi yang berkaitan dengan struktur dan fungsi bagian tanaman dengan menggunakan metode pembelajaran kooperatif tipe Jigsaw dalam kelompok besar yang dilaksanakan di dalam kelas. Setelah siklus I dilakukan, di akhir siklus I diberikan postes kepada siswa. Hasil postes pada siklus I diperoleh nilai rata-rata siswa 74,3 Presentase ketuntasan belajar siswa pada siklus I sebesar 72,7\%, hal ini belum mencapai kriteria ketuntasan secara klasikal maka penelitian ini dilanjutkan pada siklus II.

Siklus II dilaksanakan juga dengan menggunakan metode kooperatif tipe Jigsaw. Perbedaan yang terlihat pada siklus II ialah pada kegiatan pembelajarannya dalam melaksanakan metode kooperatif tipe 
Isnayani Siregar: Upaya Meningkatkan Hasil Belajar...

Jigsaw, siswa melaksanakannya tidak di dalam kelas namun memanfaatkan lingkungan sebagai sumber belajar. Tujuannya adalah agar dalam melaksanakan tugas yang diberikan oleh guru, siswa bisa menjadi lebih focus lagi dapat menghemat waktu saat siswa membentuk kelompok baru menjadi kelompok ahli. Model yang diterapkan guru ini sangat berhasil, hal ini dapat dilihat dari hasil yang diperoleh pada siklus II ini nilai rata-rata hasil belajar siswa sebesar 80,22 dengan presentase ketuntasan belajar siswa pada siklus II sebesar 90,90\% dan mencapai kriteria ketuntasan klasikal. Dari hasil siklus II ini dapat diperoleh kesimpulan bahwa dengan menggunakan metode kooperatif tipe Jigsaw dapat meningkatkan hasil belajar siswa pada pelajaran ilmu pengetahuan alam (IPA) siswa kelas IV SD Negeri 163088 Jalan Nangka Kota Tebingtinggi. Berdasarkan hasil tes yang diperoleh pada siklus II maka penelitian ini tidak perlu dilanjutkan lagi pada siklus berikutnya dan penelitian ini dapat dikatakan berhasil.

\section{SIMPULAN}

Berdasarkan hasil penelitian dan pembahasan yang disajikan dapat ditarik kesimpulan bahwa: Penggunaan metode kooperatif tipe Jigsaw dapat meningkatkan hasil belajar pada pelajaran ilmu pengetahuan alam (IPA) siswa kelas IV SD Negeri 163088 Jalan Nangka Kota Tebing tinggi tahun pembelajaran 2017/2018. hasil tes yang diperoleh saat pra siklus dimana nilai rata-rata perolehan siswa 62,5 dengan ketuntasan klasikal 40,9\%. Setelah dilaksanakan siklus I dan dilaksanakan tes diakhir siklus I terjadi peningkatan pemahaman siswa dengan nilai ratarata perolehan siswa sebesar 74,3 dan nilai ketuntasan klasikal sebesar $72,7 \%$. Selanjutanya hasil tes yang diperoleh pada siklus II nilai rata-rata siswa 80,22 dengan ketuntasan kelas sebesar 90,90\% , maka dengan ini penelitian ini dikatakan berhasil.

\section{DAFTAR RUJUKAN}

Carin, A. A., \& Sund, R. B. 1993. Teaching modern science. Merrill.

Jihad, A. 2008. Evaluasi pembelajaran. Multi Pressindo.

Analysis and design of improved antennasforGPR. Subsurfacesen singtechnologies and applications, 3(4), 295-326.

Mukhlis, A. 2000. Penelitian Tindakan Kelas. Makalah Panitia Pelatihan Penulisan Karya Ilmiah untuk Guru-guru se-Kabupaten Tuban.

Stevens, R. J., \& Slavin, R. E. 1995. The cooperative elementary school: Effects on students' achievement, attitudes, and social relations. American educational research journal, 32(2), 321-351.

Sudjana, N., \& Rivai, A. 2002. Media Pendidikan. Bandung. 